\title{
Evaluation of ground pollution by hydrocarbons using Rock-Eval pyrolysis
}

\author{
Dariusz Więcław ${ }^{1, *}$, Maria Sadlik ${ }^{2}$ \\ ${ }^{1}$ AGH University of Science and Technology, Faculty of Geology, Geophysics and Environmental Protection, \\ al. Mickiewicza 30, 30-059 Krakow, Poland \\ ${ }^{2}$ Marshal Office of the Małopolska Region, Basztowa 22, 31-156 Kraków, Poland \\ "Corresponding author: e-mail: wieclaw@agh.edu.pl
}

\begin{abstract}
The exploration and utilization of petroleum are potential hazards to the environment. Successful determination of petroleum contamination in ground relies on accurate definition of the type, source and quantity of contaminant. For this purpose the Rock-Eval ${ }^{\circledR}$ pyrolysis was applied, which is a rapid quantitative (Bulk Rock method) and qualitative (fractional composition using Multi-Heating Rates method) technique. Results of Rock-Eval analysis of 13 samples of concrete and 2 samples of gravel taken from the different sites of the petrol station indicate the highest concentration of light hydrocarbons (gasoline and naphtha fractions), up to over 5\% wt. in the direct proximity of petrol pumps. Similarly high contamination (almost 4\%wt.), was found near fuel tanks. Here the highest contribution has lubricating oil fraction and the tankers providing fuels are probably the source of this pollution. In the gravel collected in the vicinity of the fuel tanks high concentration (over 5 wt.\%) of non-pyrolyzable carbon (soot) was recorded, the source of which are probably diesel engines of fuel tankers supplying fuel.
\end{abstract}

Keywords: Rock-Eval, oil, lubricants, ground pollution, petrol station.

\section{INTRODUCTION}

The worldwide exploitation and application of petroleum as source of fuel, lubricants, solvents and synthetic materials causes a serious environmental hazards. Consequently, there is a need to protect the environment against these products not only by preventing their leakage, but also by developing methods to detect these substances in the ground environment. By developing effective methods for identifying a pollutant, its composition, origin and properties, it will be possible to locate the source of its emission and prevent it, stop the further spread of pollution and develop ways to remove it from natural environment. The up-to-date methods of determination of petroleum contaminations quantity and origin applies usually solvent extraction techniques ${ }^{\mathbf{1}, 2,3}$ followed by analysis (e.g. chromatographic) of extract. This method allows the determination of the content of individual paraffinic, naphthenic, olefin and aromatic hydrocarbons and NSO-containing compounds, although is time- and cost-consuming. For the quick estimation of the quantity of hydrocarbons polluting soil Fourier Transform Infrared Spectroscopy (FT-IR) can be used ${ }^{4,5}$. Alternatively, the pyrolitical techniques may be applied (e.g. Py-GC-FID or Py-GC-MS) ${ }^{6}$.

One of the pyrolytic methods that is suitable to analyze the hydrocarbons-polluted ground is the Rock- Eval $^{\circledR}$ programmed pyrolysis ${ }^{7}$. Currently this method is routinely used for the hydrocarbon potential analysis of source rocks in the oil and natural gas exploration studies $^{8-11}$, recent sediments ${ }^{12,13}$ or soil organic matter characterization $^{14,15}$.

The purpose of this work is to present, for the first time in literature, the feasibility of the programmed pyrolysis for estimating of quantity and determination of source of ground pollution by petroleum compounds (gasoline, diesel, lubricating and heavy oils and distillation residue) using the Rock-Eval 6 apparatus with the application of the Multi-Heating Rates (MHR) method based on data received for a selected petrol station in Cracow (Poland).

\section{MATERIALS AND METHODS}

\section{Materials}

The petrol station selected for this study has been working continuously for over 40 years. The concrete driveway was not renovated and cavities are visible. 13 samples of concrete from driveway of ca. 10 grams weight each were taken at different locations (Fig. 1) using hammer. The location of the sampling points was selected to statistically cover the station's area: both the places most exposed to pollution (at distributors and underground fuel tanks) as well as on the access and exit roads. The top layer of concrete was taken up to a depth of ca. $15 \mathrm{~mm}$. Typically, the samples consisted of fine concrete particles. Macroscopically all samples were similar to each other. Additionally 2 samples from the top layer of gravel (ca. $10 \mathrm{~g}$ each - a few pieces) near the driveway was collected (Fig. 1). Each sample was placed into separate, labelled glass jar.

\section{Methods}

Collected samples were pulverised to fraction below 0.2 $\mathrm{mm}$ in a rotary mill. For the Rock-Eval analysis ca. 50 to $100 \mathrm{mg}$ of sample was placed into a special crucible.

The screening pyrolysis was completed with a Vinci Technologies Rock-Eval 6 Turbo apparatus in Bulk Rock method using the Basic cycle for all samples. This analysis consisted of two steps. Firstly, a crucible with rock sample was loaded by autosampler into a pyrolytic oven in which in a nitrogen atmosphere (flow of $100 \mathrm{ml} / \mathrm{min}$ ) was heated from $300^{\circ} \mathrm{C}$ ( $3 \mathrm{~min}$ isothermal) to $650^{\circ} \mathrm{C}$ at $25^{\circ} \mathrm{C} / \mathrm{min}$. The generated gases were splitted $50: 50$. One portion was directed to a flame ionization detector (FID) for determination of free hydrocarbon content (released at isothermal heating at $300^{\circ} \mathrm{C}-S 1$ peak) and residual hydrocarbon content (released at $300-650^{\circ} \mathrm{C}-$ $S 2$ peak) and second one, after water and tars removal - to an infra-red cell (IR) for determination of $\mathrm{CO}$ and $\mathrm{CO}_{2}$ produced during decomposition of organic matter $(\mathrm{OM})$ and carbonates ( $\mathrm{S}, \mathrm{S} 3$ ', $\mathrm{S} 3 \mathrm{CO}$ and $\mathrm{S} 3^{\prime} \mathrm{CO}$ peaks). 
Each pyrolyzed sample was then moved by autosampler to an oxidation oven where it was heated in air flow $(100 \mathrm{ml} / \mathrm{min})$ from $300^{\circ} \mathrm{C}(1 \mathrm{~min}$ isothermal $)$ to $850^{\circ} \mathrm{C}$ at $20^{\circ} \mathrm{C} / \mathrm{min}$ (5 min isothermal at final temperature). The produced $\mathrm{CO}\left(\mathrm{S} 4 \mathrm{CO}\right.$ peak) and $\mathrm{CO}_{2}\left(\mathrm{~S}_{4} \mathrm{CO}_{2}\right.$ and $S 5$ peaks) were determined using an IR detector. Indices used for quantitative and qualitative evaluation of $\mathrm{OM}$ were calculated, i.e., pyrolytic (PC, wt.\%), residual (RC, wt.\%), total organic carbon content (TOC, wt.\%) and production index $(\mathrm{PI}=\mathrm{S} 1 /(\mathrm{S} 1+\mathrm{S} 2))$. Analytical details and formulas for calculation of $\mathrm{PC}, \mathrm{RC}$ and $\mathrm{TOC}$ are presented elsewhere ${ }^{7}$.

For selected samples (the most polluted) the Multi-Heating Rates method was applied. In this method, the beginning of pyrolysis at $90^{\circ} \mathrm{C}$ and up to 5 independent temperature rates may be set. For the current study the temperature in the pyrolytic oven was programmed: start at $120^{\circ} \mathrm{C} \mathrm{(5} \mathrm{min} \mathrm{of} \mathrm{isothermal} \mathrm{heating),} \mathrm{increase} \mathrm{of} \mathrm{the}$ temperature to $180^{\circ} \mathrm{C}$ at $10^{\circ} \mathrm{C} / \mathrm{min}(5 \mathrm{~min}$ of isothermal heating), increase to $350^{\circ} \mathrm{C}$ at $15^{\circ} \mathrm{C} / \mathrm{min}(5 \mathrm{~min}$ of isothermal heating), increase to $450^{\circ} \mathrm{C}$ at $20^{\circ} \mathrm{C} / \mathrm{min}(5$ min of isothermal heating), increase to $550^{\circ} \mathrm{C}$ at $25^{\circ} \mathrm{C} /$ min (5 min of isothermal heating) and final heating to $650^{\circ} \mathrm{C}$ at $25^{\circ} \mathrm{C} / \mathrm{min}$. This procedure allows the separation of polluting hydrocarbons into 6 fractions corresponding to temperature intervals. The quantities of hydrocarbons released in individual temperature intervals have been marked as Q0, Q1, Q2, Q3, Q4 and Q5.

\section{RESULTS}

In our study 15 samples of concrete or gravel were taken at different locations at the selected gas station (Fig. 1).

Results of the Bulk Rock method were presented in Table 1 . The free hydrocarbons content (released at $300^{\circ} \mathrm{C}$, $\mathrm{S} 1$ peak) ranges from 0.03 to $52.1 \mathrm{mg} / \mathrm{g}$, and residual hydrocarbons (released from 300 to $650^{\circ} \mathrm{C}, \mathrm{S} 2$ peak) from 0.35 to $45.4 \mathrm{mg} / \mathrm{g}$, respectively. Such variable contents of free and residual hydrocarbons result in PI values from 0.08 to 0.86 . High content of free hydrocarbons, above $10 \mathrm{mg} / \mathrm{g}$, was found in 3 samples: STB_1, STB_7 and STB_8, whereas so high residual hydrocarbons, in 4 samples: STB_1, STB_2, STB_9, STB_12 (Table 1). The exemplary pyrograms of samples rich in free and residual hydrocarbons are shown in Figure 2. The high

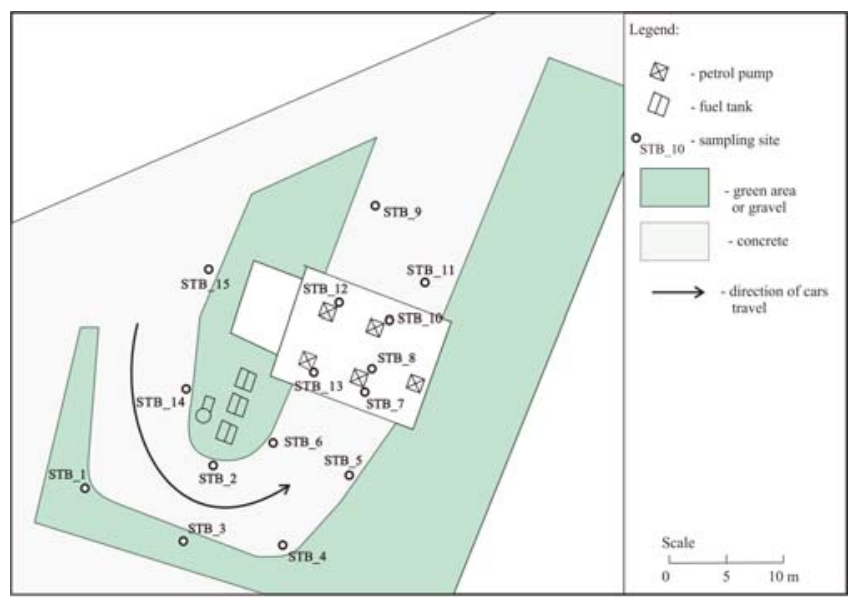

Figure 1. Sketch map of the petrol station with location of sampling sites

concentrations of hydrocarbons resulted in high, up to 5.2 wt.\% of pyrolytic carbon content (Table 1). The non-pyrolysable (residual) carbon content varies from 0.13 to $5.4 \mathrm{wt} . \%$ and the TOC values changes from 0.2 to $5.7 \mathrm{wt} \%$ (Table 1 ). The fraction of the pyrolytic
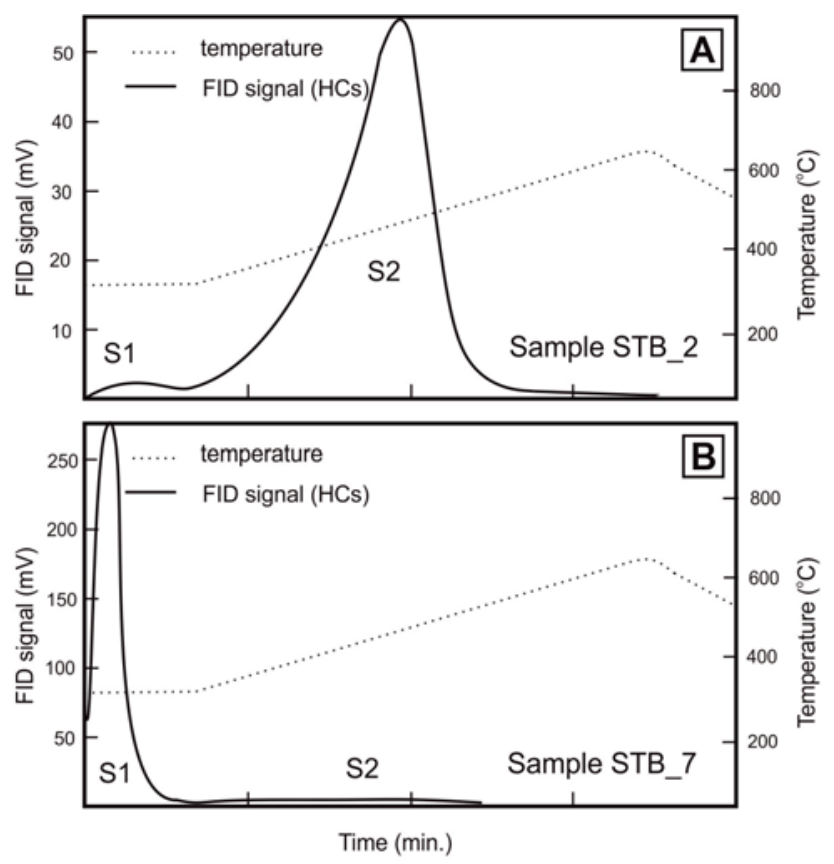

Figure 2. The FID-signals of the Bulk Rock method of (A) STB 2 and (B) STB_7 samples

Table 1. Selected parameters and indices received during Rock-Eval analysis (Bulk Rock method)

\begin{tabular}{|c|c|c|c|c|c|c|c|c|}
\hline Sample & Type of sample & $\mathrm{S} 1[\mathrm{mg} / \mathrm{g}]$ & $\mathrm{S} 2[\mathrm{mg} / \mathrm{g}]$ & $\mathrm{PI}$ & PC [wt.\%] & RC [wt.\%] & TOC [wt.\%] & $\mathrm{PC} / \mathrm{TOC}$ \\
\hline STB_1 & gravel & 17.8 & 12.1 & 0.59 & 2.7 & 1.65 & 4.3 & 0.62 \\
\hline STB_2 & concrete & 1.02 & 45.4 & 0.02 & 3.9 & 1.62 & 5.5 & 0.71 \\
\hline STB_3 & gravel & 0.12 & 2.1 & 0.05 & 0.37 & 5.4 & 5.7 & 0.06 \\
\hline STB_5 & concrete & 0.15 & 2.4 & 0.06 & 0.3 & 0.9 & 1.20 & 0.25 \\
\hline STB_6 & concrete & 1.11 & 5.0 & 0.18 & 0.6 & 0.55 & 1.15 & 0.52 \\
\hline STB_7 & concrete & 52.1 & 8.4 & 0.86 & 5.2 & 0.46 & 5.6 & 0.92 \\
\hline STB_9 & concrete & 1.49 & 20.9 & 0.07 & 1.95 & 0.26 & 2.2 & 0.88 \\
\hline STB_10 & concrete & 0.39 & 1.24 & 0.24 & 0.21 & 0.27 & 0.48 & 0.44 \\
\hline STB_11 & concrete & 1.28 & 9.4 & 0.12 & 1.13 & 2.0 & 3.2 & 0.36 \\
\hline STB_12 & concrete & 4.1 & 20.2 & 0.17 & 2.2 & 0.67 & 2.9 & 0.77 \\
\hline STB_13 & concrete & 1.01 & 5.1 & 0.16 & 0.63 & 0.35 & 0.98 & 0.64 \\
\hline STB_14 & concrete & 0.05 & 0.35 & 0.12 & 0.07 & 0.13 & 0.20 & 0.35 \\
\hline STB_15 & concrete & 0.03 & 0.44 & 0.07 & 0.08 & 0.24 & 0.32 & 0.25 \\
\hline
\end{tabular}


carbon in the total organic carbon content varies from 0.06 (STB_3) to 0.92 (STB_7) (Table 1).

Based on preliminary results (Bulk Rock method), samples STB_1, STB_2, STB_7, STB_8, STB_9 and STB_12, as the most polluted, were selected for analysis by the Multi-Heating Rates (MHR) method to identify the fractional composition of polluting hydrocarbons. The results of these samples analyses are presented in Table 2. The Fig. 3 shows examples of pyrograms received during Rock-Eval analysis using MHR method.

The concentration of fractions evaporating below $120^{\circ} \mathrm{C}$ and above $550^{\circ} \mathrm{C}$ are low and do not exceed 0.5 $\mathrm{mg} / \mathrm{g}$ rock. The concentrations of fractions released in
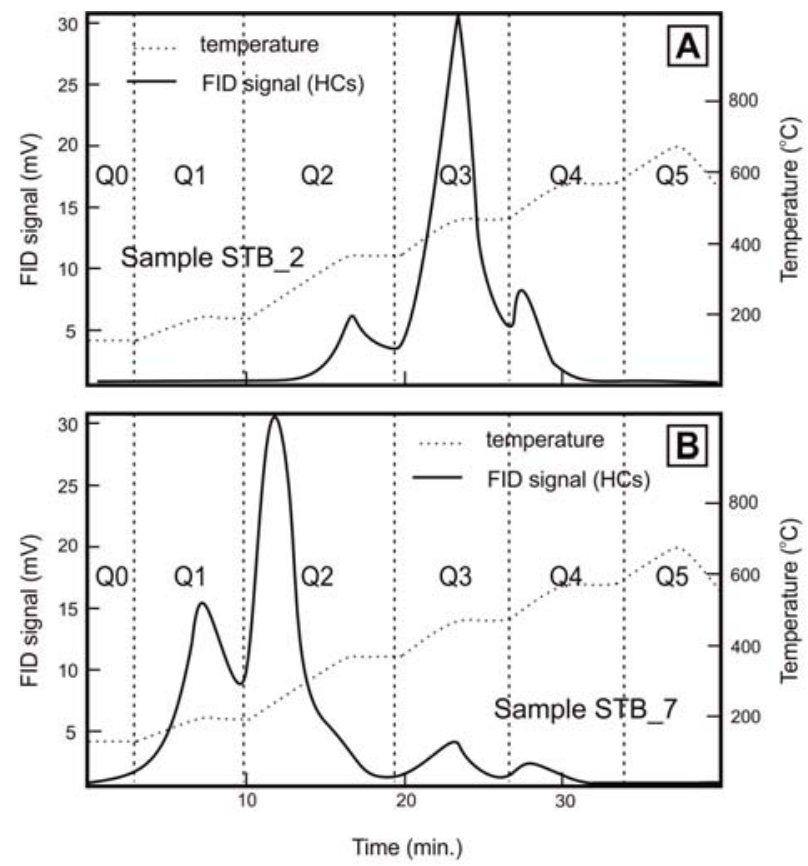

Figure 3. The FID-signals of the Multi Heating Rates method of (A) STB_2 and (B) STB_7 samples

the temperature ranges of $120-180^{\circ} \mathrm{C}$ and $450-550^{\circ} \mathrm{C}$ are higher, and vary from 0.09 to 17.1 and from 1.1 to $5.2 \mathrm{mg} / \mathrm{g}$ rock, respectively (Table 2 ). The highest concentrations are observed for fractions evaporating in the temperature ranges of $180-350^{\circ} \mathrm{C}$ and $350-450^{\circ} \mathrm{C}$ : from 3.5 to 30.8 (average $13.5 \mathrm{mg} / \mathrm{g}$ rock) and from 2.5 to 28.0 (average $12.6 \mathrm{mg} / \mathrm{g}$ rock), respectively (Table 2).

\section{DISCUSSION}

The concrete is made of cement and sand which are inherently poor in organic matter. Therefore the S1 and S2 values of two concrete samples taken outside the petrol station (STB_14 and STB_15) were assumed as the background effect associated with atmospheric pollution. Their low values of S1 and S2 (ca. $0.04 \mathrm{mg} / \mathrm{g}$ and ca. $0.40 \mathrm{mg} / \mathrm{g}$, respectively) are negligible and were considered as reference material to other samples (Fig. 4).

The distribution of hydrocarbon pollution at analyzed petrol station is presented on Figure 4. Samples containing the highest $\mathrm{HC}$ concentrations (up to $60 \mathrm{mg} / \mathrm{g}$ rock) were recorded in the direct proximity of petrol pumps (samples STB_7 and STB_8) and close to underground fuel tanks (sample STB_2). Also elevated concentrations of hydrocarbons were recorded in concrete on the exit road from the gas station (samples STB_9 and STB_11) being probably the result of spreading pollutants from distributors by vehicles. High concentration of hydrocarbons, with dominating share of light fractions $(\mathrm{PI}=0.59)$ was recorded in gravel sample collected near to underground fuel tanks (STB_1, Fig. 4). Source of pollutants in this sample is probably the same as for sample STB_2 and are connected with fuel tanks. Because the gravel is made of porphyry, which as a igneous rock is devoid of organic matter, all recorded organic material is of anthropogenic origin. Another gravel sample (STB_3), collected in the vicinity of STB_1 and STB_2 samples (Fig. 1), is much lower polluted by pyrolyzable hydrocarbons than previously described ones (Table 1, Fig. 4), but it contains comparable amount of TOC to them (Table 1). The dominating mass of organic carbon in this sample is non-pyrolyzable residual carbon (soot), the source of which is probably fuel tankers supplying fuel. Sampling point STB_3 is located close to the exhaust outlet of parked trucks.

The applied Multi-Heating Rates method allowed determining the proportion between the gasoline fraction (up to $180^{\circ} \mathrm{C}$ ), diesel oil $\left(180-350^{\circ} \mathrm{C}\right.$ ) and heavy fractions (most of all lubricating oil, above $350^{\circ} \mathrm{C}$ ) in organic material occurring in analysed samples (Table 3 ).

In the samples collected at the petrol pumps (STB_7 and STB 8) gasoline and diesel oil fractions dominate (Table 3, Fig. 5), as the result of fuels spill during refuelling of cars. Although light fractions should evaporate quickly, their concentration is considerable. This is facilitated by the roofing of the area where the fuel distributors are located and the permanent "supply" of pollutants to the ground. The sample taken in the vicinity of another fuel pump (STB_12) and from the exit way from the station (STB_9) are rich in heavy fractions (lubricating oil), evaporating at temperatures above $350^{\circ} \mathrm{C}$ (Fig. 5). The fraction of diesel oil does not exceed $30 \%$ and the gasoline fraction is below $3 \%$ (Table 3 ). These pollutants are the result of oil leaks from car engines or are the residue after partial evaporation of low-boiling gasoline and diesel oil fractions.

Table 2. Results of Rock-Eval pyrolysis (Multi Heating Rates method)

\begin{tabular}{|l|c|c|c|c|c|c|c|}
\hline Fraction & Q0 & Q1 & Q2 & Q3 & Q4 & Q5 & QT \\
\hline Temperature interval & $0-120^{\circ} \mathrm{C}$ & $120-180^{\circ} \mathrm{C}$ & $180-350^{\circ} \mathrm{C}$ & $350-450^{\circ} \mathrm{C}$ & $450-550^{\circ} \mathrm{C}$ & $550-650^{\circ} \mathrm{C}$ & \\
\hline STB_1 & 0.01 & 1.77 & 18.1 & 9.4 & 2.1 & 0.12 & 31.5 \\
\hline STB_2 & 0.01 & 0.09 & 5.4 & 28.0 & 5.2 & 0.19 & 38.9 \\
\hline STB_7 & 0.42 & 17.1 & 30.8 & 3.9 & 1.71 & 0.07 & 54.0 \\
\hline STB_8 & 0.23 & 10.0 & 16.7 & 2.5 & 1.07 & 0.04 & 30.6 \\
\hline STB_9 & 0.04 & 0.25 & 3.5 & 18.3 & 1.66 & 0.05 & 23.8 \\
\hline STB_12 & 0.03 & 0.61 & 6.8 & 13.7 & 2.5 & 0.05 & 23.7 \\
\hline
\end{tabular}

Q0, Q1, Q2, Q3, Q4, Q5 - quantity of hydrocarbons released during given temperature interval; QT - Total quantity of hydrocarbons; all values in $\mathrm{mg} / \mathrm{g}$ rock 


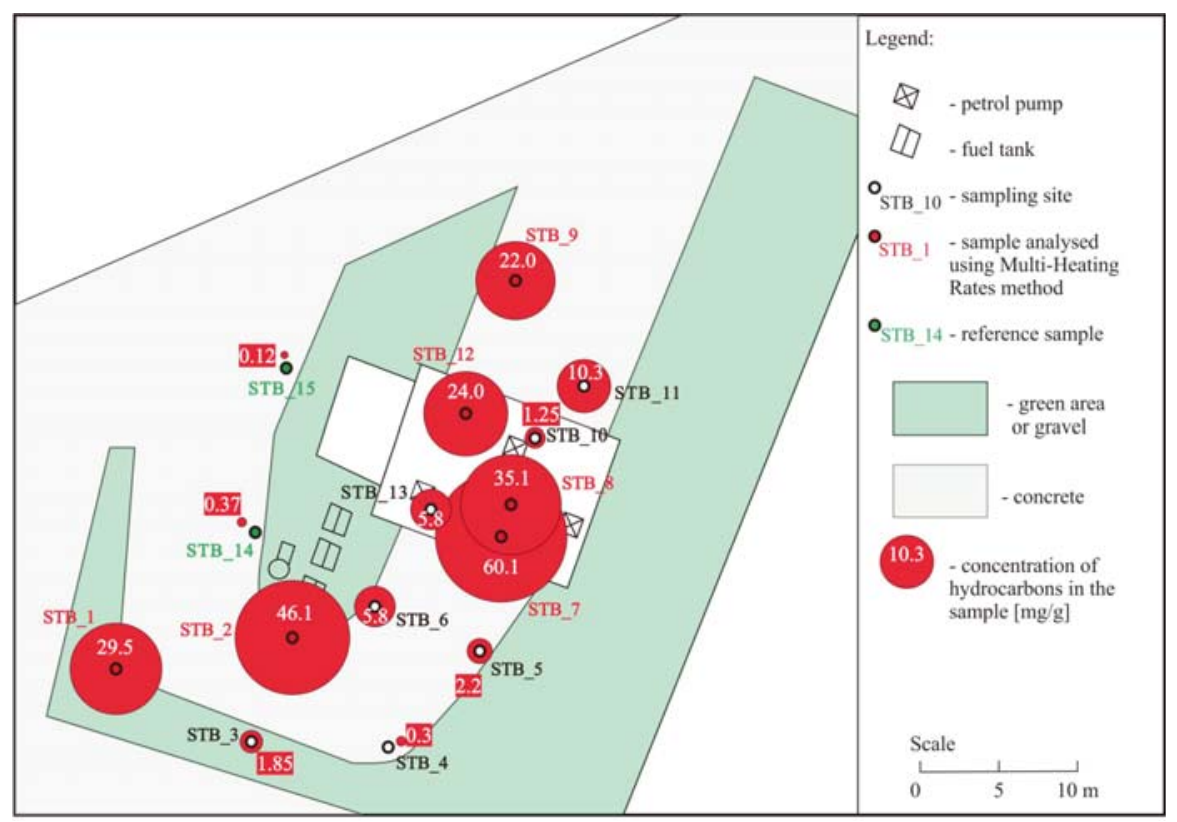

Figure 4. Distribution of the total concentration of hydrocarbons in ground samples (Bulk Rock method)

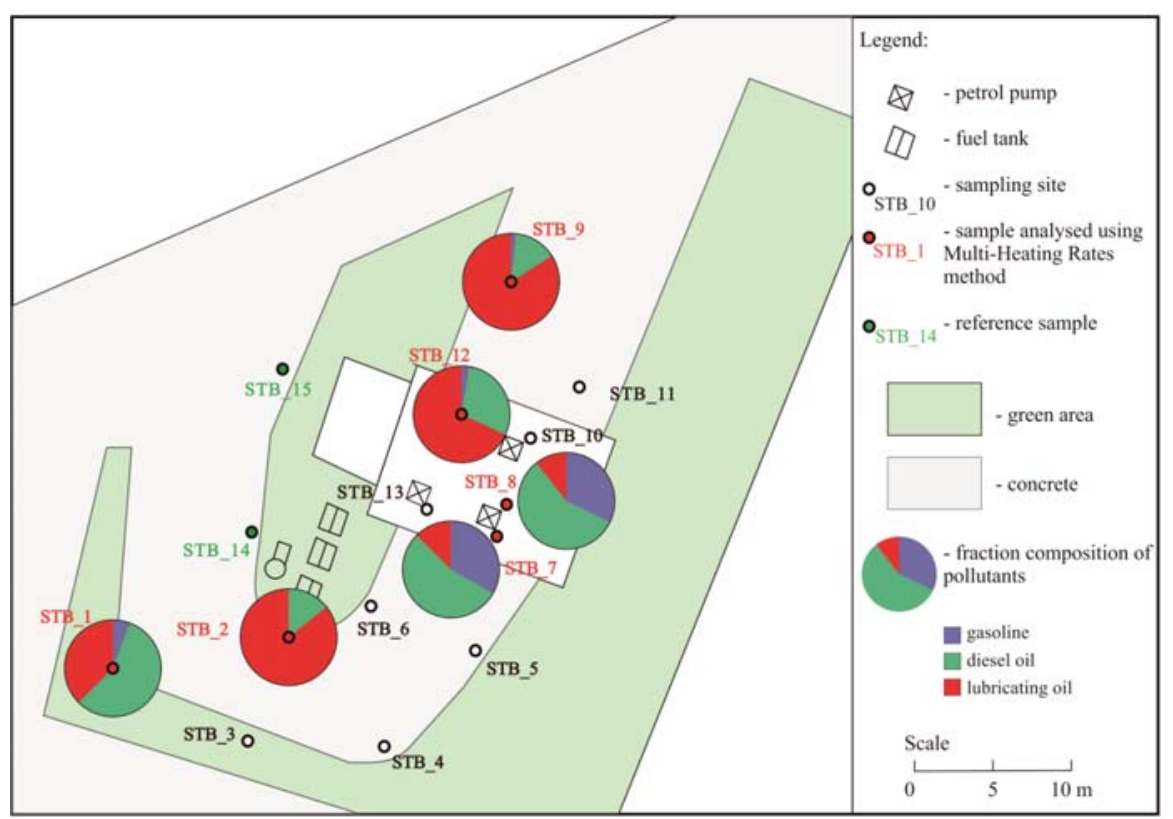

Figure 5. Fraction composition of hydrocarbons polluting ground in selected sites of the petrol station

The contamination recorded near fuel tanks (almost 4 wt.\%, sample STB_2) is dominated by heavy fractions (Table 3, Fig. 5). The source of pollution in this area may be both nearby fuel tanks (during filling - fuel spill and leaks of lubricating oil from engines and car tanker instrumentation), as well as passing cars. The neighbouring STB_1 sample is significantly enriched in lower boiled fractions (especially diesel oil) to the STB_2 sample. These pollutants are the result of the rain rinsing the most water-soluble hydrocarbons from vicinity of fuel tanks (site STB_2), and depositing them in the gravel next to the driveway (site STB_1, Fig. 5); the area around fuel tanks is not covered, therefore it is open to weather conditions.

CONCLUSIONS

The performed analyses show the possibility of using the Rock-Eval method for quickly estimate the amount

Table 3. Fraction composition of hydrocarbon pollutants

\begin{tabular}{|c|c|c|c|c|c|c|}
\hline \multirow{3}{*}{ Sample name } & \multicolumn{3}{|c|}{ Fraction [mg/g] } & \multicolumn{3}{|c|}{ Fraction composition [\%] } \\
\hline & Gasoline & Diesel oil & $\begin{array}{l}\text { Heavy fractions } \\
\text { (lubricating oil) }\end{array}$ & Gasoline & Diesel oil & $\begin{array}{c}\text { Heavy fractions } \\
\text { (lubricating oil) }\end{array}$ \\
\hline & $0-180^{\circ} \mathrm{C}$ & $180-350^{\circ} \mathrm{C}$ & $350-650^{\circ} \mathrm{C}$ & $0-180^{\circ} \mathrm{C}$ & $180-350^{\circ} \mathrm{C}$ & $350-650^{\circ} \mathrm{C}$ \\
\hline STB_2 & 0.10 & 5.4 & 33.4 & 0.3 & 14.0 & 85.8 \\
\hline STB_7 & 10.3 & 16.7 & 3.6 & 33.6 & 54.5 & 11.9 \\
\hline STB_8 & 17.5 & 30.8 & 5.7 & 32.4 & 57.0 & 10.6 \\
\hline STB_9 & 0.29 & 3.5 & 20.0 & 1.2 & 14.6 & 84.2 \\
\hline STB 12 & 0.64 & 6.8 & 16.3 & 2.7 & 28.7 & 68.6 \\
\hline
\end{tabular}


and fractional composition of hydrocarbon pollutants in grounds most exposed to hydrocarbon degradation (hydrocarbon mines, refineries, tanks, trans-shipment and petrol stations). Due to short time of analysis (ca. $1.5 \mathrm{hr}$ ), high sensitivity (0.01 $\mathrm{mg} \mathrm{HC} / \mathrm{g}$ rock) and small necessary sample (ca. $100 \mathrm{mg}$ ) it can be used to determine even traces of pollutants as alternative to long-lasting extraction using organic solvents. In addition to analyzing the amount and fractional composition of pyrolyzable hydrocarbons, this method allows to determine the amount of carbon occurring in the form of dust (soot, coke) or recent organic debris, which is not detected by extraction methods. Due to the necessary preparation of sample for analysis (homogenization, grinding), the determination of the low-boiling fractions content and composition may be erroneous. The accurate results are obtained by analyzing heavier fractions $\left(\mathrm{C}_{15+}\right)$.

Because the pyrolytical analysis is not selective, during heating of sample, there are decomposed and released all organic compounds evaporated/cracked at given temperature. Therefore, special attention must be paid to samples containing residual organic matter, not related to hydrocarbon contamination (eg. organic debris dispersed in soil or other sediments $\left.{ }^{12-15}\right)$ and before determining the amount and type of contamination, it is necessary to perform background analysis for samples collected from the same type of ground not contaminated with petroleum products.

\section{ACKNOWLEDGEMENTS}

The research was undertaken as part of the statutory project financed by the Ministry of Science and Higher Education (AGH Grant No. 11.11.140.626). Two anonymous reviewers provided very constructive reviews, which greatly improved the discussion and working hypotheses presented in the manuscript.

\section{LITERATURE CITED}

1. Alinnor, I.J. \& Nwachukwu, M.A. (2013). Determination of total petroleum hydrocarbon in soil and groundwater samples in some communities in Rivers State, Nigeria. J. Environ. Chem. Ecotoxicol. 5(11), 292-297. DOI: 10.5897/JECE2013.0298.

2. Sadler, R. \& Connell, D. (2003). Analytical Methods for the Determination of Total Petroleum Hydrocarbons in Soil. In A. Langley, M. Gilbey \& B. Kennedy (Eds.) Proceedings of the Fifth National Workshop on the Assessment of Site Contamination pp. 133-150. Environment Protection \& Heritage Council, Adelaide, Australia.

3. Sari, G.L., Trihadiningrum, Y. \& Ni'matuzahroh, N. (2018). Petroleum Hydrocarbon Pollution in Soil and Surface Water by Public Oil Fields in Wonocolo Sub-district, Indonesia. J. Ecol. Eng. 19(2), 184-193. DOI: 10.12911/22998993/82800

4. Levei, E., Senila, M., Cadar, O., Roman, M. \& Tanaselia, C. (2014). Validation of Petroleum Hydrocarbons Determination in Soil by Fourier Transform Infrared Spectroscopy. Bulletin USAMV series Agriculture 71(2), 226-230. DOI: 10.15835/ buasvmcn-agr:10432.

5. Paíga, P., Mendes, L., Albergaria, J.T. \& Delerue-Matos, C.M. (2012). Determination of total petroleum hydrocarbons in soil from different locations using infrared spectrophotometry and gas chromatography. Chem. Pap. 66(8), 711-721. DOI: 10.2478/s11696-012-0193-8.

6. Biache, C., Lorgeoux, C., Saada, A., Colombano, S. \& Faure, P. (2017). Fast method to quantify PAHs in contamina- ted soils by direct thermodesorption using analytical pyrolysis. Talanta 166, 241-248. DOI:10.1016/j.talanta.2017.01.055.

7. Lafargue, E., Marquis, F. \& Pillot, D. (1998). Rock-Eval 6 applications in hydrocarbon exploration, and soil contamination studies, Revue IFP 53(4), 421-437. DOI: 10.2516/ogst:1998036.

8. Behar, F., Beaumont V. \& De B. Penteado, H.L. (2001). Rock - Eval 6 Technology: Performances and developments. Rev. IFP 56(2), 111-134. DOI: 10.2516/ogst:2001013.

9. Dahl, B., Bojesen-Koefoed, J., Holm, A., Justwan, H., Rasmussen, E. \& Thomsen, E., (2004). A new approach to interpreting Rock-Eval S2 and TOC data for kerogen quality assessment. Org. Geochem. 35, 1461-1477. DOI: 10.1016/j. orggeochem.2004.07.003.

10. Więcław, D. (2016). Habitat and hydrocarbon potential of the Kimmeridgian strata in the central part of the Polish Lowlands. Geol. Quart. 60(1), 192-210. DOI: 10.7306/gq.1260.

11. Kotarba, M.J., Więcław, D., Bilkiewicz, E., Dziadzio, P. \& Kowalski, A. (2017). Genetic correlation of source rocks and natural gas in the Polish Outer Carpathians and Paleozoic-Mesozoic basement east of Kraków (southern Poland). Geol. Quart. 61(4), 795-824. DOI: 10.7306/gq.1367.

12. Baudin, F., Disnar, J.R., Aboussou, A. \& Savignac, F. (2015). Guidelines for Rock-Eval analysis of recent marine sediments. Org. Geochem. 86, 71-80. DOI: 10.1016/j.orggeochem.2015.06.009.

13. Carrie, J., Sanei, H. \& Stern, G. (2012). Standardisation of Rock-Eval pyrolysis for the analysis of recent sediments and soils. Org. Geochem. 46, 38-53. DOI: 10.1016/j.orggeochem.2012.01.011.

14. Hetényi, M. \& Nyilas, T. (2014). Soil organic matter characterization using S3 and S4 signals from Rock-Eval pyrolysis. Pedosphere 24(5), 563-574.

15. Hetényi, M., Nyilas, T. \& Toth, T.M. (2005). Stepwise Rock-Eval pyrolysis as a tool for typing heterogeneous organic matter in soils. J. Anal. Appl. Pyrolysis 74, 45-54. DOI: 10.1016/j.jaap.2004.11.012. 